\title{
IVAN THE TERRIBLE AND RUSSIAN FEUDALISM IN THE WORKS OF HUNGARIAN AND RUSSIAN HISTORIANS OF THE SOVIET ERA*
}

\author{
Rev. of: Szvák, G. (2019). Opyt mikroistoriografii [An Attempt at \\ Microhistoriography]. Moscow, Akvilon. 288 p.
}

\section{Charles J. Halperin}

Independent Scholar, Bloomington, Indiana, USA

In his book An Attempt at Microhistoriography (Rus. Onıım мuкроисториогpaøuu), Gyula Szvák, an outstanding Hungarian specialist in Russian history, republishes seven of his earlier articles and presents a previously unpublished eighth article on the Soviet historiography of the key issues of $16^{\text {th }}$-century Russian history. The articles consider Ivan Peresvetov's works, reforms and oprichnina between the middle and second half of the sixteenth century; also, they compare the reigns and personalities of Ivan the Terrible and Peter the Great. Additionally, the author explores the personal stories of his mentors, Russian historian Ruslan Skrynnikov and Hungarian József Perényi. The book reviewed presents a kind of panorama of two historiographic traditions of studying the Russian Middle Ages in the Soviet Union and Hungary before the collapse of the communist regime there. The author returns to the peculiarities of Russia's historical development and comprehension of the concept of "Russian feudalism" and reflects on the fate of historians who were engaged in the study of mediaeval Russia under rigid ideological principles.

Keywords: Gyula Szvák, historiography, Ivan IV, feudalism, Ruslan Skrynnikov, József Perényi.

В книге «Опыт микроисториографии» выдающийся венгерский специалист по русской истории Дюла Свак переиздал семь своих прежних и представил ранее не опубликованную восьмую статью о советской исто-

* Citation: Halperin, Ch. J. (2020). Ivan the Terrible and Russian Feudalism in the Works of Hungarian and Russian Historians of the Soviet Era. In Quaestio Rossica. Vol. 8, № 5. P. 1795-1801. DOI 10.15826/qr.2020.5.559.

Цитирование: Halperin Ch. J. Ivan the Terrible and Russian Feudalism in the Works of Hungarian and Russian Historians of the Soviet Era // Quaestio Rossica. Vol. 8. 2020. № 5. P. 1795-1801. DOI 10.15826/qr.2020.5.559.

(C) Halperin C. J., 2020

Quaestio Rossica • Vol. 8 • 2020 • № 5, p. 1795-1801 
риографии ключевых проблем истории России XVI в.: творчества Ивана Пересветова, реформ и опричнины середины - второй половины XVI столетия, сопоставления правления и личностей Ивана Грозного и Петра Beликого. Он также исследовал персональные истории своих наставников, русского историка Руслана Скрынникова и венгерского Йозефа Перени. В рецензируемом издании разворачивается своеобразная панорама двух историографических традиций изучения русского Средневековья в Советском Союзе и Венгрии до падения там коммунистического режима. Автор вновь возвращается к проблемам специфики исторического развития России, осмысления концепта «русский феодализм», размышляет о судьбах историков, занимавшихся исследованиями средневековой Руси в условиях господства жестких идеологических установок.

Ключевые слова: Дюла Свак, историография, Иван IV, феодализм, Руслан Скрынников, Йозеф Перени.

In his An Attempt at Microhistoriography (Onıьm микроисториографии), Gyula Szvák [Свак, 2019], professor emeritus of Eötvös Loránd University, Budapest, presents eight articles, seven of which were first published between the 1970s and 1980s, primarily on Soviet historiography about Ivan the Terrible and the question of feudalism in Russian history. He provides a wealth of insights into Soviet historical scholarship. Although he clearly states that his goal was to study historiography, not history, nevertheless his own historical views are of considerable interest.

The book contains a preface, seven unnumbered chapters, and another article functioning as a conclusion. Part 1 "Microhistoriographical Studies" (Микроисториограбические очерки) contains five chapters; in Part 2 "The Personality in Historiography" (Личность в историографии), there are two chapters.

In the "Foreword. From Historiographic "Microphilology" to Microhistoriography and Bеуond" (Предисловие: от исторической «микробилологии» к микроисториографии и дальше) written in 2018 (с. 5-20), Szvák provides the reader with an illuminating intellectual autobiography. He was an undergraduate student in Leningrad State University but completed his Bachelor's Degree at Eötvös Loránd University, and later, in 1984, completed his Candidate's Degree (kandidatskaia dissertatsiia) as a Corresponding (zaochnyi) graduate student, under the supervision of Ruslan Skrynnikov, on the historiography of Ivan the Terrible. He wrote his master's dissertation, defended in 1999, on the topic of feudalism in Russia, in Hungary under the supervision of József Perényi. Szvák's experience gave him an insider's view of Soviet historiography. He met leading historians and had full access to current historical publications. As a citizen of what was then called in the US a "satellite" country, he was both an insider and an outsider. An insider, because he had to adhere, however loosely, to the shibboleths of Soviet Marxist historiography, but an outsider, because he was not Soviet. The goal of his publications was to provide a bridge 
between East and West. Szvák fairly observes that despite Marxism, Soviet historians did good research, and that despite the Cold War, so did AngloSaxon historians. Although his metier was historiography, the analysis of the differing views of different historians gave him space to express his own views. The change of regime in Hungary with the overthrow of the Soviet empire created new opportunities but studying Russian history in a country that could now express considerable hostility toward Russia created difficulties. It took Szvák years to build an institutional structure for graduate study of Russia in Hungary. As a result of his outstanding organizational work, a Center and (remote) graduate program were established. However by the turn of the twenty-first century, in part because of political developments in Hungary, he had retreated from "big questions" to "small questions" (hence the neologism "microhistoriography"), although that change of focus did not for one moment impede his monumental editing, writing, and publishing activities. He retired in 2018. As of 2020 he has written or edited 143 books, mostly in Hungarian or Russian.

The first chapter in Part 1, from 1978, is "On the Assessment of Ivan Peresvetov's Activities” (К вопросу об оценке деятельности Ивана Пересветова, с. 21-56), in which Szvák primarily takes issue with assertions that Peresvetov was a heretic. He concludes that Peresvetov's influence and originality have been exaggerated and that we have no evidence that he was a spokesman for the gentry. Yet he lauds Peresvetov as a literary genius who transformed his personal dilemma into a treatise on the dilemma of Russia at the time. In passing he remarks that Peresvetov manifested an ambivalent attitude toward the Ottomans: they were better than the Greeks, but otherwise bad. Szvák makes fun of the concept of the Russian Pre-Renaissance advanced by Dmitry Likhachev by asking rhetorically if Russia could have a Pre-Renaissance if it did not have a Renaissance. Despite the bibliographic breadth of this chapter, Szvák did not have access to Werner Philipp's 1935 monograph [Philipp] or Daniel Matuszewski's 1972 doctoral dissertation [Matuszewski].

The second chapter published in two parts in 1985 and 1987, "Soviet Historiography of Reforms in the Mid- $16^{\text {th }}$ Century" (Советская uсториография реборм серединь XVI в., с. 60-137), based upon his candidate's dissertation, is exhaustive. Szvák calls into question the conflict model of relations between the boyars and the gentry, which impugns the value of Aleksandr Zimin's thesis that the government of the 1550s pursued a "policy of compromise" between the two antagonistic social classes. Nor, Szvák continues, did Zimin take sufficiently into account Vladimir Kobrin's point that the anti-brigandage legislation was instituted during the period of so-called "boyar rule," so the argument that the boyars were against centralization lacks credibility. Szvák endorses Skrynnikov's concept of the boyar class as comprised of several distinct elements, each of which had a separate policy toward the tsar's authority. It must be said that despite Szvák's personal relationship with Skrynnikov, he treats Skrynnikov's research objectively and shows no favoritism. In line with what was going 
on in US scholarship in the 1980s, Szvák called for more research in social history in order to put political history into a proper context. This chapter illustrates very well Szvák's tactic of using one Soviet historian's research to question another Soviet historian's conclusions. Given the great disagreements among Soviet historians on specific questions (not on the "Party line," of course), it was always possible for Szvák to find defensible support for his own conclusions.

The third chapter, from 1987, "The Question of the Historical Significance of the Oprichnina in Soviet Historical Studies" (Вопрос исторического значения опричнины в советской исторической науке, с. 138-196) connects both early and later Soviet scholarship on the oprichnina to imperial Russian precedents. For example, he associates Zimin's views with those of Vasily Klyuchevsky and Boris Veselovsky, and Skrynnikov's interpretation to that of Sergei Platonov and Petr Sadikov, although these connections are only suggestive. As Szvák well knew, each historian articulated his own composite and original interpretation, so it was extremely rare for any two historians to agree completely. In retrospect, the major contested issues of the late 1980s have remained unsolved for over thirty years later, none more central than, in Soviet terminology, the relative weight of objective factors (political and social history) and subjective factors (Ivan's personality) in the history of the oprichnina, in other words, how much of what happened may be ascribed to Ivan himself. Szvák scrupulously identifies the strengths and weaknesses of each publication he discusses.

The fourth chapter, the only previously unpublished essay in the book, "Some Parallels between the Images of Ivan the Terrible and Peter the Great in Russian Historical Thought" (Некоторые параллели между образами Ивана Грозного и Петра Великого в русской исторической мысли, c. 197-205) was delivered as a guest lecture at the University of Hawaii, Manoa, in 1987. Here Szvák declared (before the "change of regime" in Hungary) that Ivan the Terrible was famous for trying but failing to create a "totalitarian dictatorship" in Russia (c. 197). Both Ivan and Peter the Great were tyrants, but historians took a more ambivalent attitude toward Peter because westernization was considered a good thing. The 1860s saw the strongest criticism of Ivan, and the 1890s with Pavel Milyukov, the strongest criticism of Peter. Because of Stalinist xenophobia for the first and last time in Russian historiography Ivan became more important in Russian history than Peter. Stalin blamed Peter for class oppression but forgot Ivan's class repression. Of course, for his lecture, Szvák had to simplify some things, but his analysis is thought-provoking. It would have been marvelous if Szvák had later had the opportunity to review Kevin Platt's 2011 monograph comparing the myths of Ivan the Terrible and Peter I [Platt]. Unfortunately, this chapter would have greatly benefited from proof-reading and copyediting by a native speaker of English.

The fifth chapter, from 1988, which completes Part 1, "Concepts of 'Russian Feudalism' in Russian Historiography" (Кониепт "русский феодализм» в российской историографии, с. 206-232) pays the most 
attention to imperial Russian, not Soviet, historiography, because Soviet historiography became monotonous after Boris Grekov had laid down the Party line that Kievan Rus' was feudal. The question of feudalism in Russia cannot be separated from the problem of Russia and the West. Szvák relates the acceptance of Nikolai Pavlov-Silvansky's thesis of feudalism in medieval Russia to the political conjuncture of the time in which the Revolution of 1905 had inspired hopes that Russia would begin to develop Westernstyle parliamentary and democratic government institutions. I wonder what Szvák thinks about recent western scholarship on medieval history, and its backlash, which impugns the entire paradigm of "feudalism" as a later, artificial, and anachronistic construct.

Part 2 does not confine itself to Soviet historiography but includes postSoviet Russian historiography and Hungarian historiography.

In the first chapter in Part 2, from 2011, "R. G. Skrynnikov: The Historian and the World - the World of the Historian (Reconstruction Experience)" (Р. Г. Скрынников: историк и мир - мир историка (опьт реконструкu,uu), c. 233-248), Szvák highlights the evolution of Skrynnikov's thoughts in the 1990s as he sought to emancipate himself intellectually from Soviet historiography and to return to the democratic values of the Imperial Russian historiographic tradition. Sometimes the conflict between Skrynnikov's factographic exposition and the Procrustean bed of Soviet dogmatism before 1991 led to inconsistencies in his conclusions. No one is more qualified to explore those anomalies than Szvák. By 1991 with the publication of Tsarstvo terrora, Ivan's rational autocratic oprichnina had become Ivan's self-destructive despotic oprichnina. Szvák notes in passing his response to my emphasis upon the continuity of Skrynnikov's evaluation of Ivan ${ }^{1}$. I have no problem with Szvák's conclusion that while keeping his main points intact, Skrynnikov's exposition grew in profundity and generalization. At least in part, I would explain our different views by chronology. Szvák read Skrynnikov's publications on Ivan as they appeared, whereas I read virtually all of them in one fell swoop after 2000 when I began working in earnest on Ivan the Terrible. And, of course, I also had the benefit of reading Szvák's articles on Skrynnikov on Ivan before I wrote my own essay. Finally, Szvák has some interesting things to say on the friction between Skrynnikov and Igor' Froyanov. Szvák notes, with some disdain, that no one ever even nominated Skrynnikov for admission to the Academy of Sciences. He attributes this failure not to the competition between the Moscow and St Petersburg "schools" of Russian history but to Moscow domination of the Academy hierarchy and center-periphery attitudes. Leningrad/St. Petersburg historians did emphasize their separation from their Moscow colleagues by creating a Leningrad (now St. Petersburg) Branch (otdelenie) of the Institute of History of the Academy of Sciences, and even a separate branch of the Academy's publishing house Nauka. Nevertheless,

\footnotetext{
${ }^{1}$ Szvák did not update his reference (c. 243, n. 22) to my then unpublished article; now see [Halperin].
} 
the reasons for Skrynnikov "exclusion" from the Academy of Sciences, if it was that, require further study.

In the second chapter of Part 2, from 2012, "Parallel Biographies - the Fate of a Historian in the Soviet Union and Hungary: Brushstrokes to the Portraits of Ruslan Skrynnikov and József Perényi” (Параллельныье биограбии - судьба историка в Советском Союзе и Венгрии: итрихи к портрету Руслана Скрынникова и Йозефа Перени, с. 249-263), Szvák pays tribute to his two mentors by comparing their careers. Certainly, Perényi had greater career difficulties because he had to adjust to the imposition of Communist rule; for a while, he had to support himself by manual labor. Skrynnikov at his worst had to teach at Herzen State University instead of Leningrad State University. Skrynnikov achieved international fame, while Perényi did not receive adequate recognition in Hungary. The most interesting material in this chapter to me is the portrait of the historical profession in a "satellite" country.

An Attempt at Microhistoriography (Опыт микроисториографии) concludes with the "Instead of a Conclusion. An Attempt at Creating a New State Concept of the History of Russia" (Вместо заключения: опьты создания новой государственной кониепиии истории России, c. 264-282) from 2017. It consists of two segments, the first on the attempt of the Putin government to impose a new standard and textbook on Russian history, which ultimately failed, and the second considers Russian historical memory, revealed by several projects by the television program Imya Rossii which sponsored contests via online voting to identity the greatest heroes of Russian history and the most important historic geographic sites. I found several of Szvák's obiter dicta more interesting than the subjects of this chapter, for example, that contemporary Hungarian historians have revived the Cold War treatment of Stalin and Hitler as equally totalitarian, or that Hungarians were surprised that Leo Tolstoy did not make the topten list of the greatest personalities in Russian history.

I would have preferred if it had omitted his substitute "conclusion" and instead reprinted his 2003 article on Soviet and post-Soviet Russian historiography about Ivan from 1989 to 2001 in Part 1 [Свак, 2003]. Overall, he emphasizes the durability of Zimin's ideas and the continuity of Skrynnikov's conclusions. He remarks that Andrei Yurganov's eschatological interpretation of the oprichnina rests on no more than a guess that Ivan was thinking of the Day of Judgment when he created the oprichnina. In his last works Skrynnikov expressed similar skepticism.

Of course, in the best of all possible worlds we would have the benefit of Szvák's evaluation of the full panoply of post-Soviet Russian historiography about Ivan the Terrible, from the gamut of scholarly views to the extremism of the amateur authors of the New Chronology, the attempt to persuade the Russian Orthodox Church to canonize Ivan, and the NeoStalinists. But that would require another book. In the meantime, anyone interested in Soviet historiography, particularly about medieval and early modern Russian history, would benefit greatly from reading Opyt mikroistoriografi, another product of Gyula Szvák's outstanding scholarship. 


\section{Список литературы}

Свак Д. Еще раз об историографии царствования Ивана Грозного // Московская Русь: специфика развития / под ред. Д. Свак. Будапешт : Magyar Ruszisztika Intézet, 2003. C. 69-75.

Свак Д. Опыт микроисториографии. М. : Аквилон, 2019. 288 с.

Halperin C. J. Ruslan Skrynnikov on Ivan IV // Dubitando : Essays in Culture and History in Honor of Donald Ostrowski / ed. by B. J. Boeck et al. Bloomington, IN : Slavica Publ., 2012. P. 193-207.

Matuszewski D. C. Peresvetov: The Ottoman Example and the Muscovite State : $\mathrm{PhD}$ Diss. Washington : [S. n.], 1972. 308 p.

Philipp W. Ivan Peresvetov und seine Schriften zur Erneuerung des Moskauer Reiches. Berlin : Ost-Europa-Verlag, 1935. $123 \mathrm{~S}$.

Platt K. M. F. Terror and Greatness. Ivan and Peter as Russian Myths. Ithaca : Cornell Univ. Press, 2011. XI, 294 p.

\section{References}

Halperin, C. J. (2012). Ruslan Skrynnikov on Ivan IV. In Boeck, B. J. et al. (Ed.). Dubitando. Essays in Culture and History in Honor of Donald Ostrowski. Bloomington, IN, Slavica Publ., pp. 193-207.

Matuszewski, D. C. (1972). Peresvetov: The Ottoman Example and the Muscovite State. PhD Diss. Washington, S. n. 308 p.

Philipp, W. (1935). Ivan Peresvetov und seine Schriften zur Erneuerung des Moskauer Reiches. Berlin, Ost-Europa-Verlag. $123 \mathrm{~S}$.

Platt, K. M. F. (2011). Terror and Greatness. Ivan and Peter as Russian Myths. Ithaca, Cornell Univ. Press. XI, 294 p.

Szvák, G. (2003). Eshche raz ob istoriografii tsarstvovaniya Ivana Groznogo [Again on the Historiography of the Reign of Ivan the Terrible]. In Szvák, G. (Ed.). Moskovskaya Rus': spetsifika razvitiya. Budapest, Magyar Ruszisztika Intézet, pp. 69-75.

Szvák, G. (2019). Opyt mikroistoriografii [An Attempt at Microhistoriography]. Moscow, Akvilon. 288 p. 